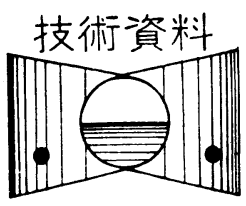

\title{
青函連絡船の船底污損が推進馬力 におよぼす影響についで
}

\section{曽 襧 正 夫**}

\author{
Influence of the Fouled Ship Bottom on the Propulsion Horsepower \\ of the Seikan Ferry-boats
}

By Masao Sone

To find out an optimum cycle of the ship bottom sweeping from the standpoint of service economics, an accurate increase in delivered horsepower due to the ship's bottom fouling was grasped and a statistical analysis was made referring to the deck logbook and the engineer's logbook in parallel with speed tests with actual vessels.

Some findings are as follows: (1) Values measured in speed tests before and after docking under conditions of 6200 tonne dwt and a given speed revealed that the annual increase in delivered horsepower due to the ship bottom fouling would be about 1000PS. (2) Variations in a decade, taking the initial service as the original point, both in delivered horsepower and in fuel consumption was at between about 10 and $15 \%$ increase.

\section{1. まえがき}

常時，海水に接している連絡船の船底部は，船底掃除 のためのドックを出てからの日数の経過につれて,フジ ツボ, アオノリなどの海洋生成物の付着が多くなってゆ くこのように, 船底部に海洋生成物の付着が増すと, 船底部は滑らかな状態ではなくなり，航走するときの摩 擦抵抗が増加して，同じ速力で航走するためには，推進 馬力は増加する。

船底部には，以前から有機砒素系の毒物を含んだ防污 効果の高い船底防污塗料を塗装して, 海洋生成物の付着 を極力少なくするように努めてきた。約 10 年ほど前か ら，ての塗料の使用が禁止されたので, 現在は, トリフ ェニル錫化合物と亜酸化銅を含んだ塗料を使用している. しかしながら，ての有機系の毒物を含まない塗料は，有 機砒素系の毒物を含んだ塗料に比べると, 防污効果の面 で劣っているのが実情である.

てのような船底部の污れによる推進馬力の増加のため, 燃料消費量も増加する. これに加えて，昭和 48 年秋に 起った石油ショックで, 燃料費の単価は一躍 3 倍以上に 高騰し, 青函連絡船の動力費は大幅に増加した.

一方に扔いて, “津軽丸”型青函連絡船屯, 多機関、 ルチプル方式による自動化船として, 津軽海峡に就航し

\footnotetext{
* 原稿受付 昭和 55 年 10 月 1 日

昭和 54 年春季学術講演 (昭和 54 年 5 月 23 日)

** 正会員 鉄道技術研究所 (国分寺市光町 2-8-38)
}

てから, 早や 14 年ないて 16 年を経過しており, 経年に よる推進馬力の增加量む十分考えられる. 従って, ての 推進馬力の増加量が, さきの船底防污塗料の防污効果の 低下による推進馬力の増加分に加味される. てのように, 連絡船はドックを出てから, 約 1 年間, 走り続けて, 次 のドックに入る時期が近くなると, 船底部の污れによる 推進馬力の増加量は相当なすのとなり, 推進機関の出力 の余裕は少なくなって, 時と場合によっては, 定時運航 が苦しくなることあ十分考えられる.

このような現状にかんがみ，青函連絡船の船底部の污 れによる推進馬力の増加量を正確には握して，運航経済 上, 最も有利な船底掃除・船底塗装の時期をみいだすと とになり，昭和 50 年 6 月から調査に着手した.

本研究では，実船による計測ならびに，ログ・ブック などを使用しての統計解析から，船底活損対策として， 6 か月船底掃除抢よびサンド・ブラスト工事を試行し， 船底部の污れが推進性能に与える影響を明らかにした。

\section{2. 調査の方法, 計測項目および計測要領}

\section{1 調査の方法}

2.1.1 調查船 調査はかつて旧海軍が, 軍港また は要港で, 長時間にわたって行った浸漬試験のデータか ら,「出きょ後の経過日数と污損量 (海洋生成物の付着量) との関係は, 出きょの時期により相違する」という理論 を主体とした，そのため，今回の調査においては，春・ 夏・秋・冬の各季節に, 船底掃除のためドック入りする 
同型船 (“津軽丸”型客貨船) 4 隻を調査船とした.

具体的には，春季調査船 (4月上旬出きょ船)：A丸，夏 季調査船 ( 6 月上旬出きょ船) : B丸, 秋季調査船 $(9$ 月下 旬出きょ船): C丸ならびに, 冬季調査船 (1 月下旬出き ょ船）：D丸である.

今回の調査における調査マップを図 1 に, 調査船の要 目を表 1 亿示す.

2.1.2 調査船による実船計測実船による計測は 次のとおりである.

（1）調查船乗組の方々の協力をえて，ドックに入る直 前 [船底部が污損された状態]および，ドックを出た直後 〔船底部が清浄な状態〕の標柱間における速力試験ならび に，それ以降，約 1 週間打きに航路上(陸奥湾内)の一定 区間における速力試験の計測.
(調 査 方 法)

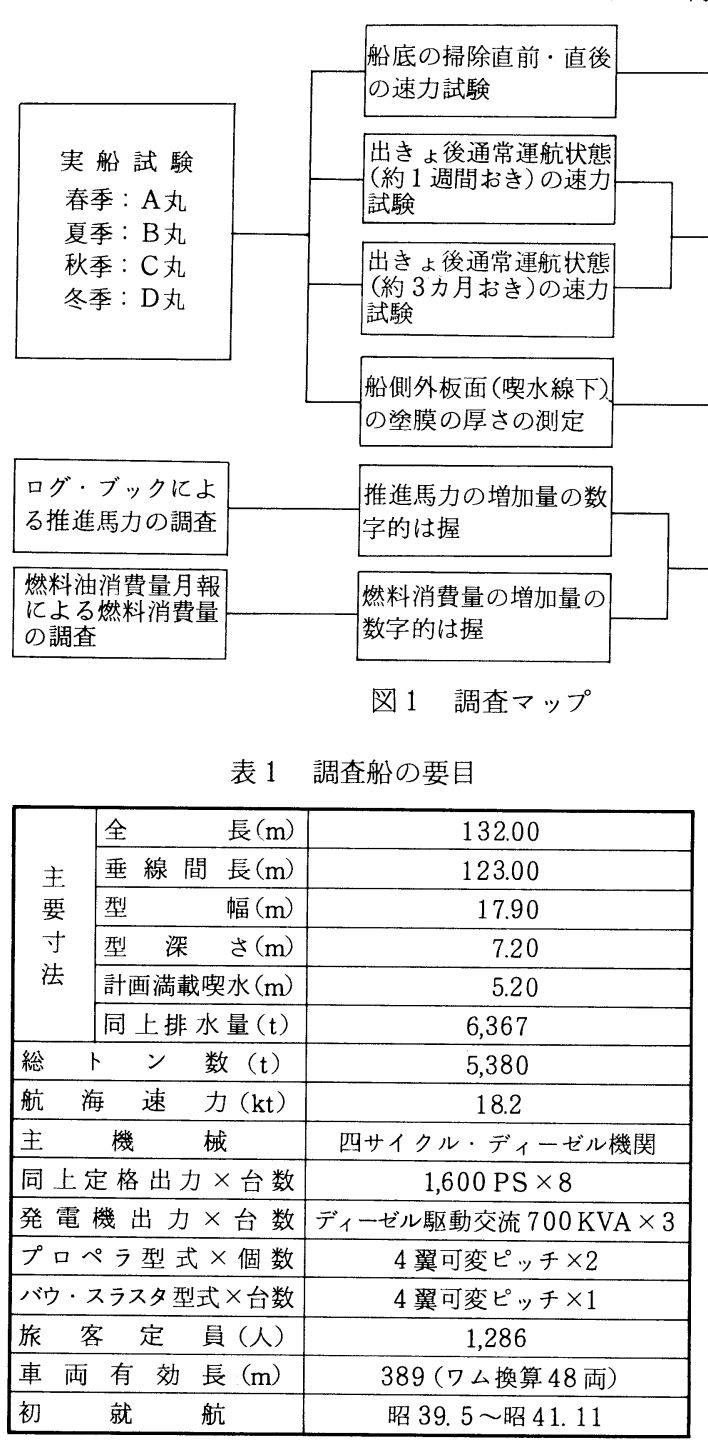

解析に当っては, 推進馬力ー可変ピッチ・プロペラの 送油管兼制御弁駆動管の動き(以下，プロペラ翼角值と (う名称を用いる)一船の速力の三者の相互関係を求め, これをあとにして, 同一の排水量, 同一の船の速力のも とで, 航走する連絡船の出きょしてからの経過日数に伴 う推進馬力の増加量の関係をは握する.

（2）調査船が船底掃除のため，入きょした直後の船側 外板面 (喫水線下) に付着した海洋生成物の観察ならびに, 出きょする直前の船底防污塗料の塗膜の厚さの計測.

調査は喫水線下の船側外板面に付着した海洋生成物の 污損状況と粗度をは握する.

2.1.3 ログ・ブックによる調査調査船の初就航 から現在までのログ・ブックに記載されている推進馬力 に関連する運航諸元をデータ（航路上の一定区間を, 速 力 17.0 ノット以上で航走し, 且つ, 風力 $10 \mathrm{~m} / \mathrm{s}$ 以下の航海状態) として, 船底部が清浄な状態における推進馬 力の経年の変化量をは握する.

2.1.4 燃料油消費量月報による 調查調査船の初就航から現在ま での，燃料油消費量月報に記載され ている青函航路 1 航海あたりの燃料 消費量 (月平均)をデータとして, 船 底部が清浄な状態のときの燃料消費 量の経年の変化量をは握する.
船側外板面の粗度 の実態は握

経年変化によもな う推進馬力, 燃費 の増加の実態は握

\subsection{1 実船による速力試験} 項目・計測要領は次のとおりである.

(1) 両舷推進軸の軸トルクの計測 両舷推進軸の軸トルクの計測は， 推進軸に接着した抵抗線ひずみ計を 使用し，FMテレメータを介して計

\section{2 計測項目之計測要領} 調查船による速力試験の際の計測

測を行った。

（2）両舷推進軸の回転数の計測両舷推進軸の回転 数の計測は, 電磁誘導型のピック・アップを船体側に取 り付け, 推進軸の 1 回転ごとのパルスを検出して計測を 行った.

(3) 両艆プロペラ翼角值の計測実際の可変ピッチ ・プロペラ翼角制御機構を, 船内で検出することが不可 能なため, 送油管兼制御弁駆動管の動き，すなわち，補 助サーボ・モータのピストン・ロットの偏位量を, 両舷 のプロペラ翼角值として計測した.

（4）速力值の計測 今回の調査における速力值の計 測は，すべて対地速力とした.てれは調査船が入きょす る直前と, 出きょした直後の速力試験において, 地上に 設備されている標柱間を使用している関係からである. また，ドックを出てから約 1 週間おきに施行した航路上 の一定区間における速力試験においても, 航路上の二地 点を使用している関係から, 対地速力值をとっている. 
そのため, 同一の試験状態で一往復の試験を行い, 潮流 や風力の影響を相殺している.

2.2.2 契水線下の船側外板面の調查調查船が船 底掃除のため，ドックに入った際の計測項目および計測 要領は次のとおりである.

（1）船側外板面 (喫水線下) に付着した海洋生成物の観 察調査船が船底掃除のため, ドックに入った面後に, 契水線下の船側外板面に付着している海洋生成物を観察 ・調查した。

（2）船側外板面(喫水線下) に塗装した船底防污塗料の 塗膜の厚さの計測調査船が船底掃除・船底塗装完了 後，ドックを出る直前に，膜厚計を使用して，船底防活 塗料の塗膜の厚さを計測した. 計測位置はキール上部 4.7 mの両舷 5 か所(Fr. No.55, 72, 89, 107 および 125) で，その位置を中心に垂直および水平方向，おのおの 5 $\mathrm{mm}$ 間隔とし，40点ずつについて計測を行った.

\section{3. 調査結果の解析}

\section{1 調査船による実船計測結果の解析}

3.1.1 調査船の速力試験の成績 今回の調査にお いて, 調査船がドックに入る直前および, ドックを出た 直後に行った速力試験の成績之, 新造時の海上試運転の 際の速力試験の成績との対比から，下記のことが判明し た.

ここに一例として，C丸の成績を図 2.1 亿示す.

(1) 調查船の船底部が清浄な状態のときの, 経年によ る速力試験の成績の対比調査船がドックを出た直後 の, 船底部が清浄な状態のときの速力試験の成績と, 新 造時の海上試運転の際の速力試験における成績とを比較 する。

例えば，C丸では図 2.1 から，排水量 6,200トン，速 力 18 ノットで航走するとき, 新造時の海上試運転の際 の速力試験の成績 (鎖線)よりも, 今回の出きょした直後 の速力試験の成績 (実線) の方が, 推進馬力で約 $400 \mathrm{PS}$ の馬力増加がみられている，また，プロペラ翼角值を 25 度としてみると, 約 0.2 ノットの速力の低下がみられ ている.

この二つの変動量は, いずれあ新造後, 約 16 年を経 過したC丸の経年による影響量とみることが出来る.

（2）調査船の船底部が清浄な状態のときの速力試験の 成績之, 污損された状態のときの速力試験の成績との対 比調査船が出きょした直後の, 船底部が清浄な状態 のときの速力試験の成績と, 約 1 年間走り続けたのちの 入きょする直前の船底部が污損された状態のときの速力 試験の成績とを比較する.

例えば，C丸では図2.1 から，排水量 6.200 トン，速 力 18 ノットで航走するとき, 初年度の入きょする直前 の速力試験の成績 (破線) と, 出きょした直後の速力試験 の成績 (実線)とを比較すると, 推進馬力の増加量は約 1,500 PSが知られる.
注 1 . 排水量 $6,200 \mathrm{t}$

2. 一x一出きょ直後の成績

--・-- 入きょ直前の成績 (初年度)

入きょ直前の成績 (次年度) (プロペラ取替後)

-・-・-・新造時の成績

サンド・ブラスト施行直前

- の成績

ロ サンド・ブラスト施行直後

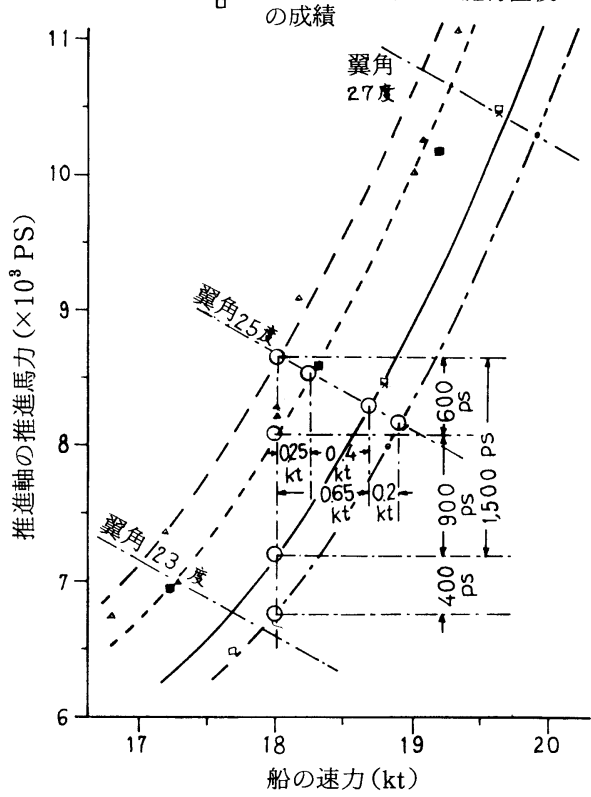

図 2.1 速力試験の成績 (C丸)

また，上記の出きょした直後の速力試験の成績 (実線) と, 出きょしてから, 約 1 年間走り続けたのちの, 翌年 度の入きょする直前の速力試験の成績 (小さな破線)とを 比較する. 図 2.1 から馬力増加量は約 $900 \mathrm{PS}$ が知られ る.

実は, 初年度のドック工事において, 両舷推進器用プ ロペラ全翼の新替えを行ったため, 次年度の成績をとおし て前者の推進馬力の増加量約 1,500 PSをみると, プロペ ラ全翼の取り替えによる影響量と，船底部の污れによる 増加量が加算された值とみるととが出来る. また，後者 の推進馬力の増加量約 $900 \mathrm{PS}$ ，船底部の污れのみに よる増加量とみることができる，このことから，C丸で は船底部の污れのみによる影響量は約 $900 \mathrm{PS}$ みるこ とが出来る.

また，プロペラ翼角值を 25 度で航走するとき，前記 のように分析すると，船底部の污れのみによる影響量は 約 0.40 ノットとみるととが出来る.

なお, 通常の運航状態の際の推進馬力は約 7,000 PS, 船の速力はほぼ 17.5 ノットである.

（3）調査船のプロペラ全翼を新替えしたことによる影 響量連絡船の推進器用プロペラ翼表面の污損度は想

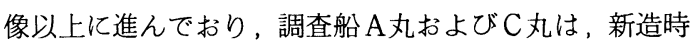
から使用していたプロペラ翼が, 翼重量で約 5\%, 肉厚 
で約 $18 \%$ の衰耗が見られたそそのため，前項に記した ように, 検査工事の際に, プロペラ全翼 (4 翼 $\times 2$ 軸)の 新替えを行った。

例えば，C丸について，排水量 6,200トン，速力 18 / ットで航走するとき，前項で記したように，プロペラ全 翼を新替えしたことにより, 推進馬力で約 $600 \mathrm{PS}$, 速 力で約 0.25 ノットの増加がみられた.

このととから、プロペラ全翼を新替えしたととによる 推進馬力抢よび速力への影響は無視するととは出来ない.

調査船に使用している可変ピッチ・プロペラの要目を 表 2 亿示す.

表 2 調査船に使用している可変ピッチ・ プロペラ要目

\begin{tabular}{|c|c|}
\hline 型 & KaMeWa 102/4 型 \\
\hline プロペラ直径 & $3,250 \mathrm{~mm}$ \\
\hline ボス直径 & $1,020 \mathrm{~mm}$ \\
\hline $\begin{array}{c}ヒ^{\circ} \text { チ比 } \\
(0.7 \mathrm{R} \text { Rおける) }\end{array}$ & 0.984 \\
\hline 数 & 4 \\
\hline 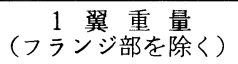 & 約 $630 \mathrm{~kg}$ \\
\hline 栈 & $\mathrm{BC} 2$ \\
\hline 定格回転数 & $217.5 \mathrm{rpm}$ \\
\hline
\end{tabular}

3.1 .2 燃料消費量の変動 調查船の船底掃除のた め,ドックに入る直前と、ドックを出た直後におてなっ た速力試験の際に，燃料消費量ああわせて計測した.

こてに一例として, C丸の成績を図 2.2 亿示す.

（1）調査船の船底部が清浄な状態のときの速力試験の 成績と, 污損された状態のときの速力試験の成績とを対 比する.

例えば，C丸では図 2.2 から，排水量 6,200 トン, 速 力 18 ノットで航走するとき, 初年度の入きょ直前と,

注 1 . 排水量 $6,200 \mathrm{t}$

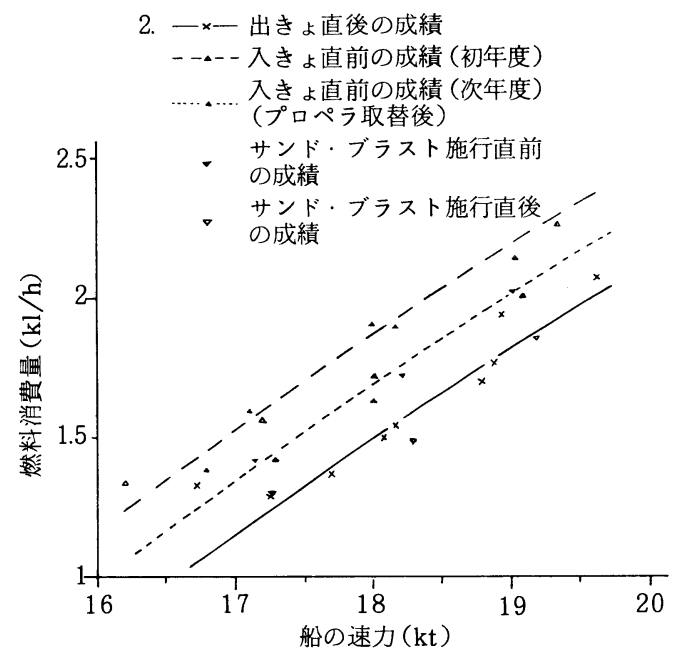

図 2.2 速力試験の成績 (C丸)
出きょ面後の速力試験の成績を比較すると, 船底部の污 れによる燃料消費量の增加量は約 $350 \mathrm{l} / \mathrm{h}$ である.

（2）調査船のプロペラ全翼を新替えしたことによる影 響をみる。

例えば，C丸では図 2.2 から，排水量 6,200 トン，速 力 18 ノットで航走するとき, プロペラ全翼を新替えし たととにより, 約 $150 \mathrm{l} / \mathrm{h}$ の燃料消費量の減少がみられ た.

3.1.3 経過日数に伴う推進馬力の変化 連絡船は ドックで船底掃除・船底塗装を施行したのち, 次のドック に入るまで約 1 年間航走するが，その間に推進馬力がど のような增加量の傾向を示すかを, さきの図 1 亿よる調 査をふまえてみる.

調査は, 調査船のドックを出た直後の速力試験の成績 を零べースとして, 出きょ後の日数の経過に伴う推進馬 力の增加量の変化を図 3 亿示す (標準状態 ${ }^{* 1}$ 亿換算).

なお, 調査船 4 船の成績は, 実際には時系列になって いるが，乙こではドック出きょ時を起点としてあわせた.

図 3 から，下記のととが判明した.

(1) 調查船の推進馬力の増加量の変化についてみる.

（a）B丸(夏季調査船：破線） 6 月下旬にドック を出たあと，約 200 日（12月中旬）を過ぎるてろまで, なだらかに増加する.のち，約 250 日 (翌年 2 月中旬)と ろから，増加量は急速にふえる傾向である.

（b） C丸（秋季調査船：鎖線） 9 月下旬にドック を出たあと, 約 100 日（12月下旬）乙ろまで, 急速に増 加がみられる. 以後は，ほほ，なだらかに增える傾向で ある。

（c） D丸（冬季調査船：小さな破線） 1 月下旬に ドックを出たあと，約 100 日 (4 月上旬)とろまで急速に 増加する．その後はほぼ一定である。

また, D丸の推進馬力の増加量の変化は, 上記のC丸 の増加量の変化と, ほぼ, 同様の増加傾向を示している. しかし，出きょしてから，約 1 年後の入きょする直前の

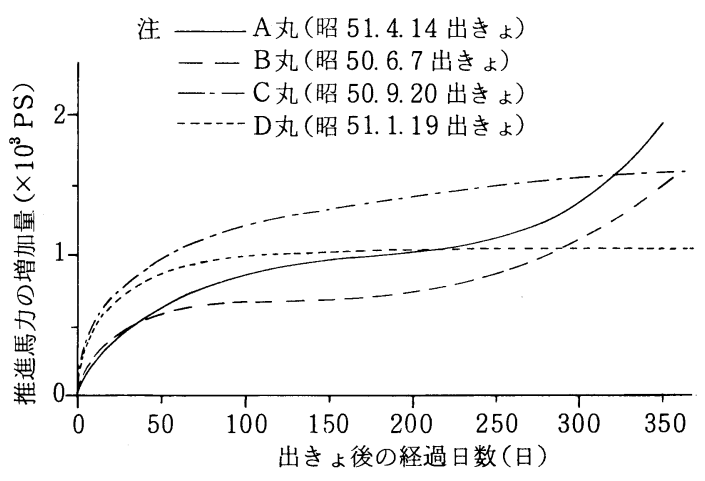

図 3 推進馬力の増加量之出きょ後の経過日数

${ }^{* 1}$ 本稿では，D丸の航海実績から，排水量 6,200 トン，速力 17.6 ノット，推進軸の定格回転数 $217.5 \mathrm{rpm}$ の 3 要素を, 今回の調査における標準状態とした. 
推進馬力の増加量を, C丸と比較す ると, 約 $600 \mathrm{PS}$ 程度, D丸の方が 低い数值を示している.

（d） A丸（春季調査船：実線）

4 月下旬にドックを出たあと，約 150 日 (9 月上旬) ころまで, やや急 速に増加する.のち、落ちついたか にみえたが，約 250 日 (12月中旬) ころから, 増加量は急激にふえる傾 向がみられる.

また，A丸の推進馬力の增加量の 変化は, 上記の B丸の增加量の変化 と，ほほ，同様の増加傾向を示して いる. しかし，出きょしてから約 1 年後の入きょする直前の推進馬力の 増加量を, B丸之比較すると, 約 400 PS程度, A丸の方が高い数値 を示している.

このように, 調査船 4 船の調査を

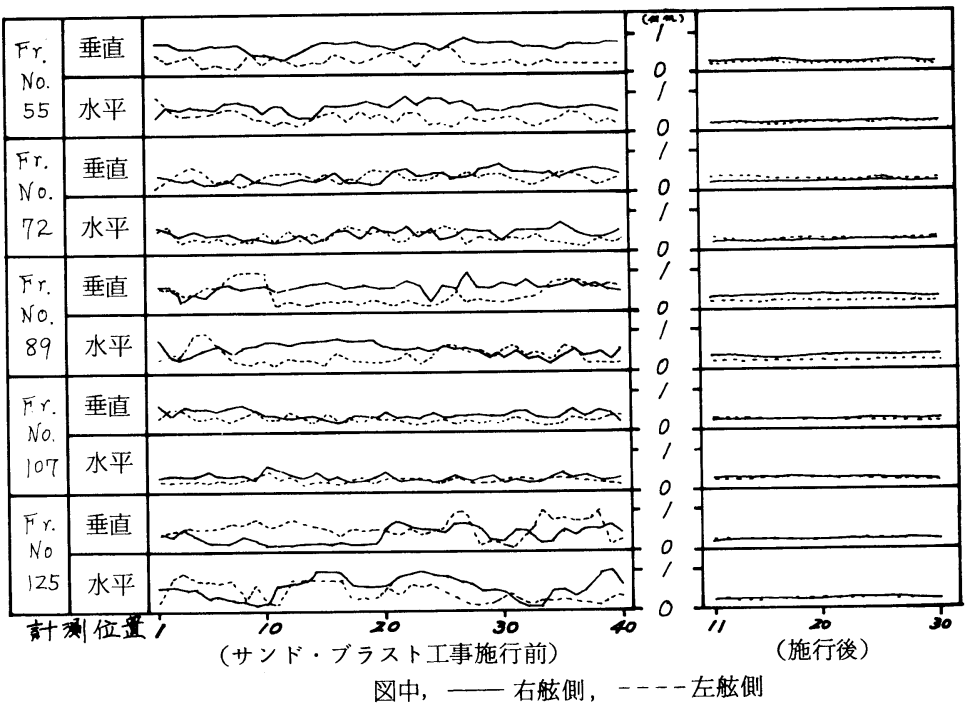

図 4 船側外板 (喫水線下) の塗膜の厚さ (C丸)

通じて, 出きょ後の日数の経過に伴う推進馬力の增加量 の変化は, 出きょの時期により相違しているととが知ら れる.

（2）調査船が出きょしてから, 約 1 年間, 走り続けた のち，翌年度の入きょするまでの推進馬力の増加割合を みると, 約 15〜25\%の増加割合を示している.

3.1.4 船側外板面(契水線下) の污損状況

（1）船側外板面 (喫水線下) 亿付着した海洋生成物の付 着状況調查船の喫水線下の船側外板面に付着した海 洋生成物の付着状況を, 調査船がドックに入った直後に 目視により観察をおこなった。

観察の結果を下記に示す.

（a）いずれの調查船においても，海洋生成物の船側 外板面一の付着状況は, 船首側 - 中央部側 - 船尾側と大 別して観察を行ったが，両舷とあ，あまり大きな差はみ られない。

（b）いずれの調查船においても，海洋生成物の付着 は，喫水線約 $3 \mathrm{~m}$ 以下の浸水部にはあまりみられていな い.

この原因は太陽光線による影響ではないかと思われる.

なお，調査船以外の乗組員の方々，ならびに造船所関 係者から屯, 連絡船の契水線下の船側外板面に付着する 海洋生成物の付着状況について取材したが，いずれあ上 述の状況之大差ない。

（2）契水線下の船側外板面に塗装した船底防污塗料の 塗膜の厚さの調査連絡船の喫水線下の船側外板面は 新造の際，一様に船底防污塗装を施したのち，毎年行わ れる船底掃除のためのドックにおいて，船底防污塗料の 塗り重ねにより，船側外板面には船底防污塗料がたい積 する.そのため, 調査船について, 初就航後, 14 年な いし 16 年を経過した船側外板面の塗膜の厚さを，船底

防污塗装の完了後、ドックを出きょする直前に測定を行 った。

調査結果から下記のととが判明した.

こてに一例として，C丸の成績を図 4 (左側)に示す.

(a) 垂直方向では下方に下がるにつれて, 塗膜の厚 さはやや薄くなってゆく傾向を示している. また, 水平 方向では凹凹がはげしくみられている.

(b) 調査船 4 船の計測点における水平の塗膜の厚さ は約 500 ミクロンで, 最大值は約 $1 \mathrm{~mm} に$ あ達している. このように, 初就航後, 14 年ないし 16 年を経過した 調査船の契水線下の船側外板面は, 船底掃除後の船底防 污塗料の塗り重ねにより, 粗度は非常に増加しているこ とが知られた。

3.2. ログ・ブックおよび燃料油消費量月報によ る統計解析

3.2.1 ログ・ブックによる推進馬力の解析 調査 船の初就航から見在まで使用しているログ・ブックをと 扎して, 航路上(陸奥湾内)の一定区間に㧍ける推進馬力 の経年変化をみる.

ここで一番問題となるのは，推進馬力の推定である.

今回の解析に当っては，“津軽丸”型青函連絡船 7 隻 の新造時の海上試運転の際の速力試験(標柱間使用)の成 績から、プロペラ翼角值一推進馬力の関係をみると, 図 5 に示すと扔りである.

いま, 図 5 から通常の運航状態に扔いて使用している プロペラ翼角值 ( 22 度から 27 度まで)一推進馬力の関係 をみると，二次式として推定出来る，そのため，個々の 調査船に扔いても，今回の航路上の一定区間で航走した 際の推進馬力に関連する回帰方程式を算出するとともに， ログ・ブックのなかから, プロペラ翼角值, 推進軸の回 転数, 速力値扔よび排水量の四つの変動量から対応する 


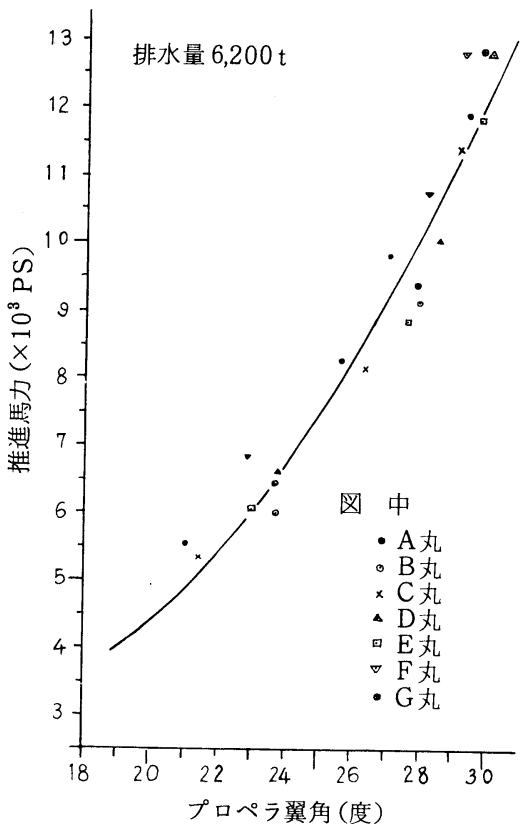

図 5 新造時の推進馬力とプロペラ翼角

推進馬力 (換算値)を推定した.

なお, 調查船の初就航からの経年による推進馬力の増 加割合は次式により算定した.

$$
\Delta P=\frac{P_{\mathrm{a}}-P_{\mathrm{s}}}{P_{\mathrm{s}}} \times 100
$$

ここに,

$\Delta P$ : 調査船の新造時の海上試運転の際の速力試験の成

績を零ベースとしたときの推進馬力の増加割合 (\%).

$P_{\mathrm{a}}:$ 調査船のログ・ブ

ックから採取したプ

ロペラ翼角值を, 新

造時の海上試運転に

おける速力試験の成

績値に換算した推進

馬力 (PS).

$=P\left(\frac{\Delta_{\mathrm{s}}}{\Delta}\right)^{p} \cdot\left(\frac{V_{\mathrm{s}}}{V}\right)^{q} \cdot\left(\frac{R}{R_{\mathrm{s}}}\right)^{r}$

$P:$ 調査船のログ・ブ

ックから採取した機

側プロペラ翼角值

に対応する推進馬力

(PS).

$\Delta_{\mathrm{s}}$ : 調査船の新造時の

海上試運転の速力試

験の際の排水量 $($ ト ン).

$\Delta:$ 調査船のログ・ブ

Journal of the M.E.S. J., Vol.16, No.2

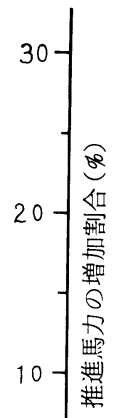

ックから採取した排水量 (トン).

$V_{\mathrm{s}}$ : 調査船の新造時の海上試運転の速力試験の際の速 力 (ノット).

$V:$ 調査船のログ・ブックから採取した船の速力(ノッ ト).

$R:$ 調査船のログ・ブックから採取した推進軸の回転 数 ( $\mathrm{rpm})$.

$R_{\mathrm{s}}$ : 調查船の推進軸の定格回転数 ( $\left.\mathrm{rpm}\right)$. $=217.5$ ( $\mathrm{rpm})$.

$P_{\mathrm{s}}$ : 調査船の新造時の海上試運転の速力試験の際の推 進馬力 (PS).

$p \cdot q \cdot r$ : 係数（新造時の海上試運転の速力試験における 成績，および今回の調査の際の入きょ直前と，出き よ直後におこなわれた速力試験の成績から算出した 数值).

今回の解析では，上式により調査船の 1 運航便ごとの 増加割合を算出し，乙れを月ごとにまとめて，その月の 馬力増加割合とした.

ここに一例として，C丸の上り便の算定值を図 6 に示 す. 図 6 から下記のととが判明した.

(a) 算定值を風力が $5 \mathrm{~m} / \mathrm{s}$ 以下 (実線) と，6〜10 m/ $\mathrm{s}$ (破線)の 2 段階に分割して, 風力による面加ら馬力増 加変動をみたが，乙の段階では差は読みとれなかった．

（b）算定值を初就航後，今日まで調查船に使用してい る船底防污塗料の種別による面からみたが, 差ははっき りとは読みとれなかった. しかしながら，傾向として有 機砒素系の毒物を含んだ防污効果の高い船底防污塗料 (商品名：アルガ $\mathrm{A} / \mathrm{F}$ )を使用していた時期 ( $\mathrm{C} 丸 て ゙ は$ 昭 和 42 年 8 月より昭和 45 年 8 月まで使用)よりも, 有機 系の毒物を含まない塗料 (商品名：エクセル $\mathrm{A} / \mathrm{F}$ )を使

注 1 .

$$
\begin{aligned}
& \text { - 風力 } 0 \sim 5 \mathrm{~m} / \mathrm{s} \\
& --- \text { : 風力 } 6 \sim 10 \mathrm{~m} / \mathrm{s}
\end{aligned}
$$

2. ○印は出きょ直後の值
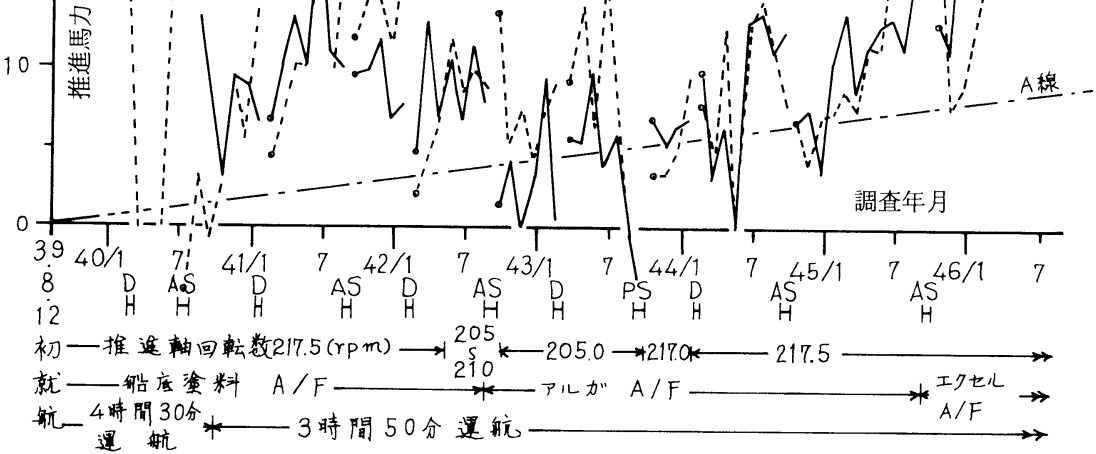

困 6 推進馬力の変化 (C丸) 
用していた時期 (C丸では昭和 45 年 8 月以降)の方が, 当然のととながら, 推進馬力の増加の傾向が高いように 感じられた。

（c）いずれの調査船でも，ドックを出た直後に船底部 は清净な状態にかえると考えると, 毎回のドックを出た 直後の算定值のみを対象として, 初就航を原点として回 帰線 (A 線と仮称する)を引くと, 横軸に対して斜線 (鎖 線)のように図示できる. このとき，A線から横軸に垂 線をおろすと，乙の值が経年による推進軸の推進馬力の 増加割合を表わしているとみることが出来る.なお，調 查船 4 船の初就航後， 10 年を経過した推進馬力の増加 割合をみると, 約 10〜15\%の増加割合を示している.

3.2.2 燃料油消費量月報による燃料消費量の解析 調査船の初就航から現在までの燃料油消費量月報をと おして，1航海当りの燃料消費量 (月平均)の経年変化を みる。

ここに一例として，C丸の経年による 1 航海当りの燃 料消費量 (月平均) の変化を図 7 に示す. 図 7 から下記の ことが判明した。

（a）調查船の 1 航海当りの燃料消費量 (月平均)の増加 傾向を, 初就航後, 今日まで使用している船底防污塗料 の種別による面からみたが，差ははっきりとは読みとれ なかった. さきの推進馬力の増加量の傾向と同様に, 燃 料消費量む有機砒素系の毒物を含んだ防污効果の高い船 底防污塗料を使用していた時期よりあ, 有機砣素系の毒 物を含まない塗料を使用していた時期の方が，当然のて とながら，増加の傾向が高いように感じられた．

（b）さきの図 6 と同様に，船底掃除のためのドックを 出た直後の 1 航海当りの燃料消費量 (月平均) の值のみを 対象として, 初就航を原点として回㷌線(A線と仮称す る)を引くと，横軸に対して斜線 (鎖線)のように図示で
きる.なお， $\mathrm{A}$ 線から調査船 4 船の初就航後，10 年を 経過した燃料消費量の増加割合をみると，約 10〜 16\% の増加割合を示している. この值は，さきの推進馬力の 経年にとあなう増加の傾向によく類似している.

（c）図6に示した経年による推進馬力の増加割合と, 図 7 に示した経年による 1 航海当りの燃料消費量(月平 均)の関係をみると，いずれの調査船においても相関し ている.

\section{3 船底污損対策としての施策}

3.3.1 6 加船底掃除 調査船の約 1 年間にわた る実船試験の結果, 今後の船底掃除・船底塗装時期を選 択する一手段として，ドックを出てから，次のドックに 入るまでのほぼ中間の時期に，船底部の掃除および塗装 のみを施行する 6 か月船底掃除以下，甲種中間工事と いう名称を用いる了を試験的におてない，工事日数を 2 日間とした。

掃除区域は，ミドロ類・アオノリ類などが多量に付着 する船体浸水部の契水線下から，ビルジキールまでの船 側外板面で, 圧力水 (約 $75 \mathrm{~kg} / \mathrm{cm}^{2}$ )を使用して，海洋生 成物を吹き飛ばしたのち，船底防污塗料(施工面積 1,450 $\mathrm{m}^{2}$ )を再塗布するという極めて簡単な作業で, 試験的に

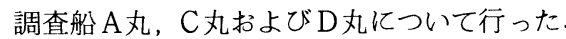

甲種中間工事を試行した際の実船試験および燃料油消 費量月報を使用しての調査結果から，下記のととが判明 した

こてに一例として，C丸の甲種中間工事を試行した前 後の推進馬力の馬力増加量の変化および， 1 航海当りの 燃料消費量(月平均)の成績を図 8 に示す.

図 8 から，下記のことが判明した。

（a）C丸の甲種中間工事 (試行)は，さきの船底掃除の ためのドックを出てから 208 日目である.

（b）甲種中間工事(試 行)を実施した直後の 1 航海当りの燃料消費量は， 実施直前と比べて，約 $630 l$ の減少がみられた。

なお，通常の運航状態 における 1 航海当りの主 機械燃料消費量は約 6,000 $l$ である。

(c) 甲種中間工事 (試 行)を実施していない前 年度の 1 航海当りの燃料 消費量亡, 施行後の成績 とを比較する.

50 年度の検査工事後 の成績 (鎖線) と，51年 度の甲種中間工事(試行) の成績 (実線) との間のほ ぼ三角形に類似した面積

困 7 燃料消費量の変化 (C丸) 

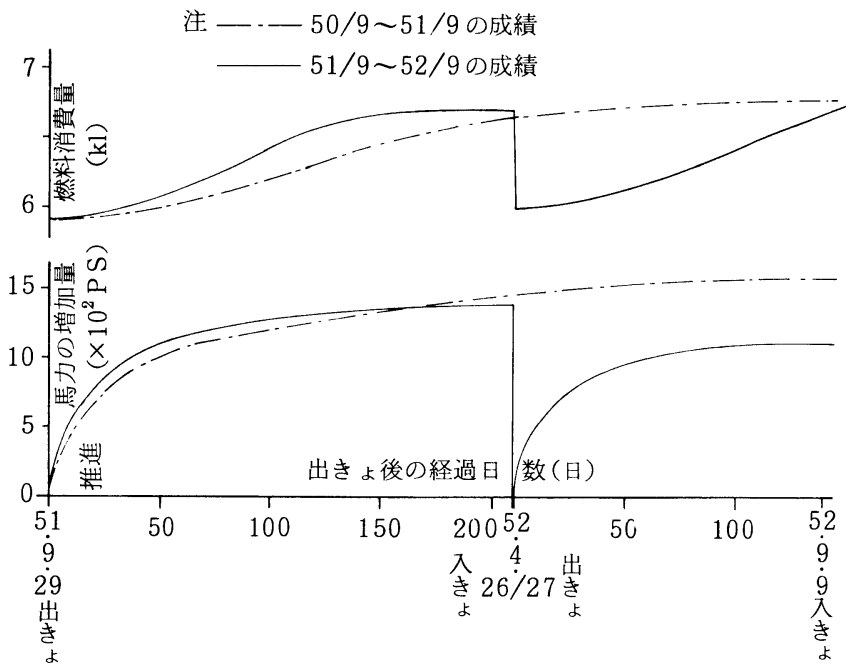

図 8 中間工事によあなう変化 (C丸)

が年間における燃料消費量の節約量とみるととが出来る. また， 50 年度の回帰曲線の延長上に，51 年度の成績が あどるのに，C丸では約 140 日を要している.

（d）今回はC丸のほかに，A丸およびD丸についてあ， 甲種中間工事を試行したが, 甲種中間工事を実施する時 期により，推進馬力および燃料消費量に相違がみられた. このととは，さきの出きょの時期により，海洋生成物の 付着量に相違がみられるととと同一である.

（e）甲種中間工事(試行) の直前と直後に，標柱間を使 用して速力試験を実施したが, 推進馬力の計測值は, 前 回のドックを出た直後の零ベースの状態にかえっており， 甲種中間工事(試行)を実施することにより, 船底部は清 浄な状態にもどっているとみるととが出来る.

3.3.2 船底部のサンド・ブラスト工事*2

契水線 下の船側外板面にたい積した船底防污塗膜の凹凸面を， 新造時のような金属肌を出すまで平滑に回復させ，船体 抵抗抢よび機関出力をあ軽減し，燃料消費量をむ合わせ て節減しようというもくろみで, 昭和 53 年 8 月，C丸 の中間検査工事の際に，サンド・ブラスト工事を試験的 に実施した。

サンド・ブラスト工事の実施に当っては，昭和 42 年 加 45 年にかけて, 防污効果の高い船底防污塗料 (商品 名：アルガ A/F)を使用していた関係から，その防污主 剂である有機砒素系の毒物が旧塗膜に残っており，環境 公害の恐れが十分考えられた。 そのため，昭和 53 年 3 月，旧塗膜について化学分析を行い，有機吪素系の毒物 の検出がみられなかったことから, 実施に踏み切った。

今回のサンド・ブラスト工事に扰ける施行区域は，船

*2 サンド・ブラスト工事 : 金属表面に付着したさび・スケー ル・塗膜などに，砂(今回は細かく粉砕した鉱さいを使用し た)を 5 ないし $7 \mathrm{~kg} / \mathrm{cm}^{2}$ の圧縮空気で噴射して清掃する 工法である.
体浸水部の契水線下とし, 施行面積 $2,680 \mathrm{~m}^{2}$ で，工事日数は約 6 日間である.

サンド・ブラスト工事を施行したC丸の実 船調査結果は次のとおりである.

（1）ドックを出きょする直前に，再度，船 底防污塗料の塗膜の厚さを計測した。

C丸のサンド・ブラスト工事施行後の計測 值を図 4 (右側) に示す. 平均の叙膜の厚さは 約 250 ミクロン(限度 210 ミクロン以上)で, 凹凸面はみられず，ほぼ，一様に塗られてい るのが知られた。

（2）入きょ直前抢よび，出きょ直後に行っ た速力試験の成績をみる.

(a) 図 2.1 にサンド・ブラスト工事施行 直前・直後( $\boldsymbol{\square}$ 印, 口印)の速力試験の際の成 績值を記載した，施行直後には，いずれの原 因からか，想像していた程，新造時の状態に はあどっていない.

（b）図 2.2 に, 上記速力試験の際の燃料消費量の計 測值 ( $\boldsymbol{\nabla}$ 印, $\nabla$ 印) ああわせて記載した。

排水量 6,200 トン, 速力 18 ノットで航走するとき, サ ンド・ブラスト工事を施行することにより, 約 $200 \mathrm{l} / \mathrm{h}$ の燃料消費量の減少がみられた。

3.3.3 船底污損対策の施策の効果 調査船を使用 して, 船底污損対策として推進器用プロペラ全翼の新替 え，甲種中間工事抢よび船底部のサンド・ブラスト工事を 試行したので, ここにC丸をとおして，その効果をみる.

（1）燃料消費量の変化 昭和 49 年 9 月の中間検査 工事施行以降の燃料油消費量月報を使用して，C丸の燃 料消費量の変化を図 9 に示す.

図9から下記のことが知られる.

（a）通常の運航状態における 1 航海当りの主機械の 燃料消費量 (昭和 50 年 9 月， 中間検査工事まで)は約 $6,000 l$ である.

（b）推進器用プロペラ全翼の新替え（昭和 50 年 9 月,

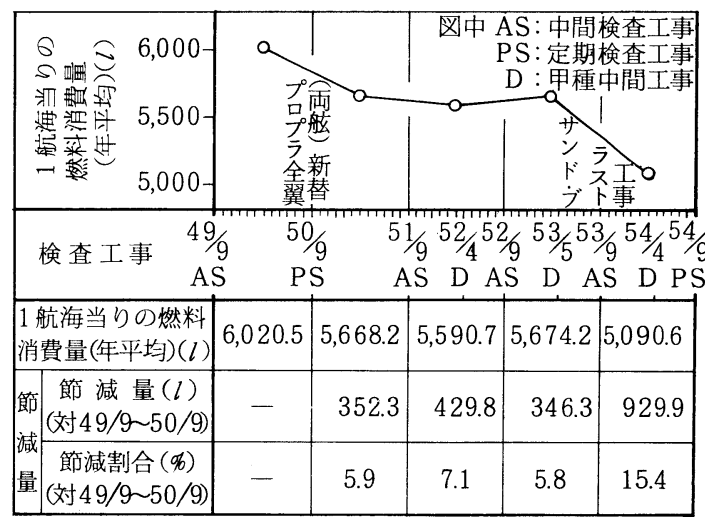

困 91 航海当りの主機械の燃料消費量 (年平均) の変化 (C丸) 
中間検査工事)により, 1 航海当り約 $350 l$ (節減割合 5.9 \%)の減少がみられた。

（c）初めての甲種中間工事を昭和 52 年 4 月に施行 した. 昭和 50 年度の検査工事後の昭和 50 年 9 月から, 昭和 51 年 9 月までの燃料消費量と, 昭和 51 年および 52 年度の検査工事後の昭和 51 年 9 月から昭和 53 年 9 月ま での燃料消費量とを比較すると, 1 航海当り約 $35 l$ (節 減割合 $0.6 \%)$ 减少がみられている.

(d) サンド・ブラスト工事を昭和 53 年 9 月 (中間検 查工事)に施行した。

（i）昭和 49 年度の検查工事後の昭和 49 年 9 月から 昭和 50 年 9 月までの燃料消費量と, 昭和 53 年度の検査 工事後の昭和 53 年 9 月から昭和 54 年 9 月までの燃料消 費量とを比較すると, 1 航海当り約 $930 l$ (節減割合 15.4 \%)の減少がみられている.

(ii）前項の節減割合 $15.4 \%$ を分析する．上記，節減 割合 $15.4 \%$ のには, 推進器用プロペラ全翼の新替えお よび甲種中間工事による影響量も含まれているととから 分担割合をみる. 昭和 49 年度ないし 53 年度の成績から 考察すると, 両舷の推進器用プロペラ全翼の新替えによ る影響量は $5.9 \%$ ，甲種中間工事による影響量は $0.6 \%$ ， サンド・ブラスト工事のみによる影響量は $8.9 \%$ となる.

（2）主機械加動台数の変化青函連絡船の主機械は 常用負荷 $85 \%$ を限度として, 通常の出力変化に対して, 8 台保有している主機械のうちから, 加動台数の変動に より対処している. そのため, 推進器用プロペラ全翼の 新替え, 甲種中間工事および船底部のサンド・ブラスト 工事による出力减は，1 運航当りの主機械加動台数の減 少となって表われる.

船底污損には直接, 関係はないが，C丸の主機械か動 台数の変化を困 10 に示す.

図 10 から下記のととが知られる.

サンド・ブラスト工事施行前の, 昭和 49 年度の検査工 事後の昭和 49 年 9 月加ら昭和 50 年 9 月までの成績亡, 施 行後の昭和 53 年度の検査工事後の昭和 53 年 9 月から昭 和 54 年 9 月までの成績とを対比すると，サンド・ブラ スト施行後には主機械か動台数は 0.9 台分減少がみられ る.

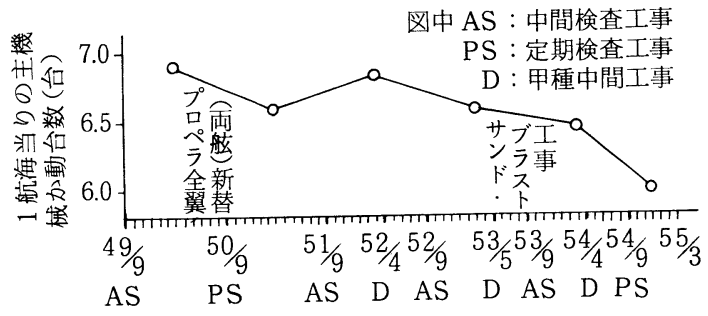

図 101 航海当りの主機械加動台数の 変化 (C丸)

\section{4.むすび}

今回の実船調査，ログ・ブックなどを使用しての統計 解析ならびに, 船底污損対策としての諸工事により下記 のことが判明した。

\section{1 実船による推進馬力の増加量}

（1）船底污損による年間の推進馬力の増加量は, 排水 量 6,200トンとして, 同一速力において, 調査船の検査工 事の直前之直後の速力試験の計測值加らると, 約 900 〜1,000 PSである.

なお, 通常の運航状態の際の推進馬力は約 7,000 PSで ある・

（2）調查船のプロペラ全翼を新替えしたてとによる影 響量は，同一速力において，約 500〜600 PSである.

（3）出きょ後の経過日数に伴う推進軸の推進馬力の増 加量は, 出きょ時を零べースとすると, 調査船の出きょ の時期により, 増加傾向が相違している.

（4）初就航後, 10 年以上を経過した調査船の喫水線 下の船側外板面に塗装した船底防污塗料の塗膜の厚さは, 船底掃除後の船底防污塗料の塗り重ねにより, 平均値で 約 500 ミクロン, 最大值は約 $1 \mathrm{~mm}$ に達しており, 粗 度は非常に増加している。

\section{2 ログ・ブックおよび燃料消費量月報による} 経年変化

（1）調査船の経年による推進馬力および燃料消費量の 変化を, 初就航後, 今日まで使用している船底防污塗料 の種別による面からみたが，いずれも差ははっきりとは 読みとれなかった。

（2）調查船の船底掃除完了直後の, 船底部が清浄な状 態のときの推進馬力および燃料消費量の変化を, 初就航 を原点としてみると，10 年間で約 10〜 $15 \%$ の増加割合 を示していた。

\section{3 船底活損対策としての施策}

4.3.1 甲種中間工事今後の船底掃除・船底塗装 時期を選択する一手段として，ドックを出てから，次の ドックに入るまでのほぼ中間の時期に，甲種中間工事を 試験的に行った.

（1）甲種中間工事を実施した直後の，1 航海当りの燃 料消費量は, 実施直前に比べて, 約 $600 l$ の差がみられ た。な招，通常の運航状態における 1 航海当りの主機械 の燃料消費量は約 $6,000 l$ である.

（2）甲種中間工事(試行)を施行する時期により，推進 馬力および燃料消費量の成績值が大分，相違しているて とが知られた。乙れは，さきの船底污損における出きょ の時期により，増加傾向が相違しているととと同一と思 われる.

4.3.2 船底部のサンド・ブラスト工事 喫水線下 の船側外板面にたい積した船底防污塗膜の凹凹面を平滑 にするため, サンド・ブラスト工事を試験的に実施した.

（1）サンド・ブラスト工事施行後の平均の塗膜の厚さ 
は約 250 ミクロンで，凹凸面はみられず，ほぼ一様に塗 られているのが知られた。

（2）C丸に沶いて，今回の調査を開始する直前の，昭 和 49 年度の検査工事後の昭和 49 年 9 月から昭和 50 年 9 月までの燃料消費量と, サンド・ブラスト工事施行後 の昭和 53 年度の検査工事後の昭和 53 年 9 月から昭和 54 年 9 月までの燃料消費量を比較すると，サンド・ブラス 卜工事施行後には， 1 航海当り約 $930 l$ (節減割合 $15.4 \%)$ の減少がみられた。

（3）前項の節減割合 $15.4 \%$ を分析する．C丸は，昭和 49 年度から昭和 53 年度までの間に, 推進器用プロペラ 全翼の新替え，甲種中間工事 (3 回)およびサンド・ブラ スト工事を施行したので，成績值から考察するとプロペ ラ全翼の新替えによる影響量は $5.9 \%$ ，甲種中間工事によ る影響量は $0.6 \%$ ，サンド・ブラスト工事による影響量は $8.9 \%$ となる。

（4）青函連絡船の主機械加動台数は，8台保有してい る主機械のうち出力変化により変動する.C丸に打ける 昭和 49 年度検査工事以降の主機械か動台数をみると, 昭和 55 年 3 月には 0.9 台分減少しているのがみられる。

\section{5.あとがき}

今回の調査をとおして, 船底部の污れが推進性能に与 える影響の大きいととを今更ながら知らされた。

実船による測定では，一般の商船でもまだ類例のない 検相工事直前の標柱間を使用しての速力試験をと扑て,
前述のような成果をうるととが出来た．

また，推進軸のプロペラ全翼の新替え，試験的に施行し た船底掃除・船底塗装のみを主体とする甲種中間工事㧈 よび船底部のサンド・ブラスト工事は，前記のように所 期の目的を達するととができ, 昭和 54 年度には客貨船 全船 (7 隻)に実施した.

上記の施策により, 昭和 54 年度末には, 昭和 49 年度 に比して青函連絡船全船で年間 $7,000 \mathrm{kl}$ という膨大な燃 料消費量の節減に成功するとと屯に, 出力負荷の軽減に より, 主機械加動台数・故障件数屯減少し, 乗組員の作 業条件の緩和，ならびに修䌜費の減少にもつながったて とは，見逃せない大きな効果であった。

\section{文献}

1) 山県昌夫, 船型学 (抵抗篇), 昭 16 .

2）出淵 巽，船底の污れによる船体抵抗の増加，造船協会会 報第 55 号，昭 $9 \cdot 12$.

3）伊藤一男, 実用船舶推進論, 船の科学, 29 巻 1 号 32 巻 2 号, 昭 $51 \cdot 11 \sim$ 昭 $54 \cdot 2$

4）隈元 士，船用プロペラと軸系.

5）宮内・曾禣，津軽丸型連絡船のシーマージンに関する統計 的調查，鉄研報告 No.909，昭和 $49 \cdot 8$.

6）曽袢他 4 名, 青函連絡船の船底污損が推進馬力におよぼす 影響について (第 1 報)，鉄研速報 No.78-6，昭 53.1.

7）岸良檘，国鉄連絡船におりる燃料節減対策，マリン・エ ンジニア, No.391, 昭 $54 \cdot 10$. 